\title{
Shellfish from the Bronze Age Site of Clos des Châtaigniers (Mathieu, Normandy, France)
}

\section{Caroline Mougne ${ }^{1}$, Catherine Dupont ${ }^{2}$, David Giazzon³ Laurent Quesnel ${ }^{4}$}

Cite this as: Mougne, C., Dupont, C., Giazzon, D. and Quesnel, L. (2014). Shellfish from the Bronze Age Site of Clos des Châtaigniers (Mathieu, Normandy, France), 'Human Exploitation of Aquatic Landscapes' special issue (ed. Ricardo Fernandes and John Meadows), Internet Archaeology. doi:10.11141/ia.37.5

1. University of Rennes 1, UMR $6566 \underline{\mathrm{CReAAH}}$, Campus de Beaulieu, Bât 24-25, 263 avenue de Général Leclerc, CS 74205, 35042 Rennes CEDEX. Email: caroline.mougne@gmail.com

2. CNRS, UMR $6566 C R e A A H$, Campus de Beaulieu, Bât 24-25, 263 avenue de Général Leclerc, CS 74205, 35042 Rennes CEDEX.catherine.dupont@univ-rennes1.fr

3. INRAP, UMR $6566 C R e A A H$, Base INRAP de Bourguébus, 4 boulevard de l'Europe, 14540 Bourguébus. Email: david.giazzon@inrap.fr

4. CNRS, UMR 6566 CReAAH, Campus de Beaulieu, Bât 24-25, 263 avenue de Général Leclerc, CS 74205, 35042 Rennes CEDEX. Email:laurent.quesnel@univ-rennes1.fr

Key words: Bronze Age, Normandy, shellfish, mussel, diet, culinary practices, stomach contents of fish

This issue has been funded by the Graduate School "Human Development in Landscapes", University of Kiel with additional funding from the Institute for Ecosystem Research, University of Kiel and the Centre for Baltic and Scandinavian Archaeology, Schloss Gottorf.

(C) Author(s). Except where otherwise noted, content from this work may be used under the terms of the Creative Commons Attribution 3.0 Unported licence, which permits unrestricted use, 


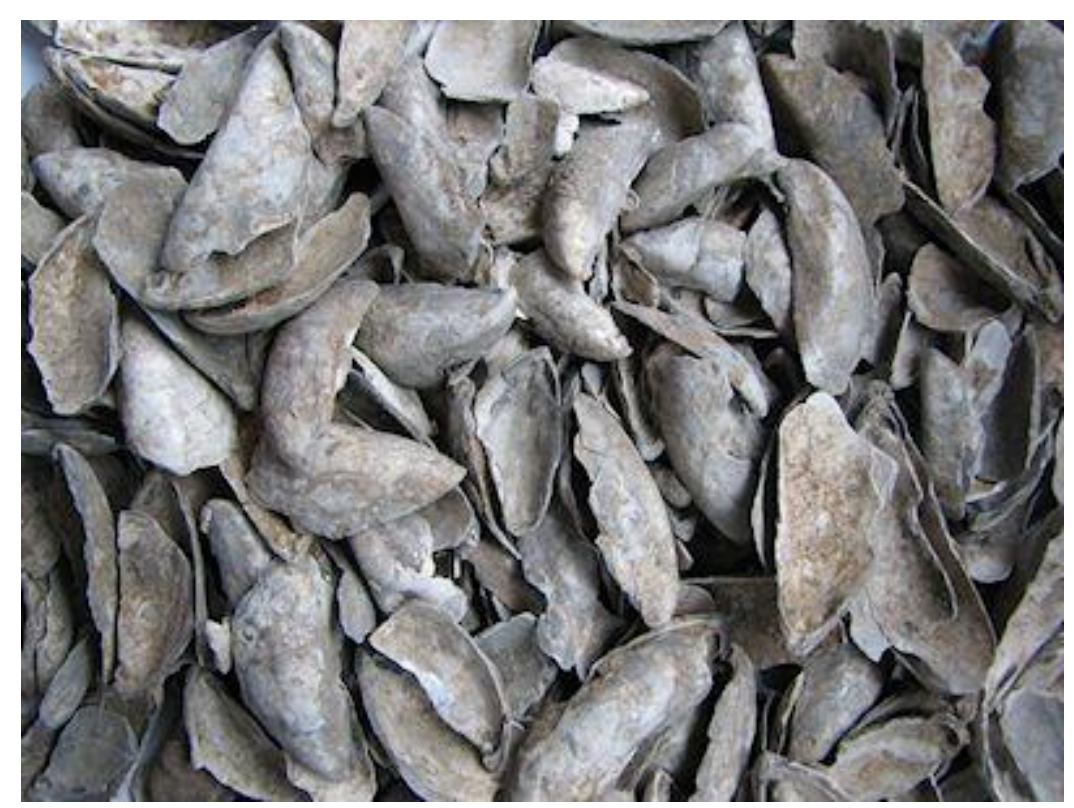

This article provides initial results on the use of shellfish by the inhabitants of Clos des Châtaigniers, Normandy (France) during the Late Bronze Age. The settlement is located at Mathieu, $10 \mathrm{~km}$ from the coast. The French National Institute of Preventive Archaeological Research (INRAP) conducted excavations on this site in 2010, under the direction of David Giazzon. A semi-circular domestic enclosure from the end of the Late Bronze Age was discovered. The diet of the inhabitants of Mathieu was partly based on mussels, which were found in large quantities. These shells were collected at low tide on a rocky to muddy/rocky shore. They were then transported inland to be eaten fresh or processed. Other marine invertebrates were also present on this site. Some of them were collected with the mussels. In fact, they were mixed with or fixed to this bivalve. Many other small fragments of shells are present on the site and could have come from the stomach contents of fish. 


\section{List of Figures}

Figure 1: Location and map of the archaeological site of Clos des Châtaigniers at Mathieu. (Image credit: D. Giazzon, L. Quesnel, C. Mougne)

Figure 2: Identified Marine invertebrates at Clos des Châtaigniers. (Image credit: C. Mougne)

Figure 3: Spectrum of the marine invertebrates at Clos des Châtaigniers.

Figure 4: Distribution of reconstructed length (1) classes $(\mathrm{mm})$ of Mytilus edulis, from a small part near the teeth (2). ( $\mathrm{N}=$ number of valves) (Image credit (mussel): L. Quesnel)

Figure 5: Tide range and substrates of the marine species (grey cell: potential presence; + : present; $(+)$ : more rarely present; after Dupont 2006a).

Figure 6: Spatial distribution of the marine invertebrates from the percentage of the NISP. (Image credit: D. Giazzon, L. Quesnel, C. Mougne)

Figure 7: Traces of burning on left valves of mussels (Mytilus edulis) in the shell accumulation no.7. (Image credit: C. Mougne)

Figure 8: Spectrum of the burned or unburned remains of mussels and barnacles by shell accumulations in percentage of the NISP. (Image credit: D. Giazzon, L. Quesnel, C. Mougne)

Figure 9: Shell remains in accumulation no.7. (Image credit: C. Mougne)

Figure 10: Examples of fishes present in Normandy nowadays, consumed by men and who have a diet based partially on marine shells ( + : consumption of marine shellfish; Muus et al. 2005; Teletchea 2009).

Figure 11: Spectrum of the bivalve remains (excepted the mussels) by shell accumulations. (Image credit: D. Giazzon, L. Quesnel, C. Mougne) 


\section{Introduction}

This article presents the archaeomalacological study of the site of Clos des Châtaigniers, at Mathieu (Normandy, France). The interest of such a study is that it is one of the first on the Channel coast dated to the Bronze Age. In fact, for this period, there are few studies on the exploitation of shellfish by the coastal populations in France (Weydert 1994; Dupont 2008; 2011; 2013; Mougne in prep), and especially on the Channel coast (Mougne and Dupont 2012; Mougne and Dupont in press). The same applies to other European countries, where some studies have been undertaken (for example: McCormick et al. 1996; Prummel 2002; Minniti 2005; Theodoropoulou 2007; 2008; Çakirlar 2009; Marlasca Martín 2010; Law 2012).

Five objectives guide this study. The first is to characterise the marine invertebrates discovered on the site, then to establish whether their gathering was intentional (e.g. for human consumption) or accidental, in order to generate some data on the diet of the inhabitants. These data make it possible to define the environments exploited and the gathering methods used. The third objective tries to identify some culinary practices linked to the preparation and cooking of marine shells. Then, it seems interesting to carry out a spatial distribution of the shells within the settlement, in order to obtain information on the management of marine waste and on the possible presence of some preparation or consumption areas. The final objective aims at analysing a particular set of small fragments of shellfish, which could have originated from the stomach contents of aquatic animals.

\section{Description of the Site}

The Clos des Châtaigniers was excavated in 2010 by the French National Institute of Preventive Archaeological Research (INRAP), under the direction of David Giazzon (Giazzon 2013). This domestic settlement is located approximately $10 \mathrm{~km}$ from the seashore, close to the River Dan, a tributary of the Orne. The archaeologists discovered a vast semi-circular structure, both pottery and radiocarbon dating assigning it to the Late 
Bronze Age (Cal BC 1190-980, Cal BC 1000-840, Cal BC 1050-900, Cal BC 1020-900 and Cal BC 970-820). This enclosure consists of two joined ditches, with a V-shaped profile, reaching $1.6 \mathrm{~m}$ to $2 \mathrm{~m}$ in depth. This structure is open on its northern side and is associated with numerous structures, mostly post-holes, but also some pits and a large combustion structure. The archaeological material is not very abundant. A small amount of slag and some fragments of crucible seem to indicate an activity linked with metallurgy. This hypothesis is reinforced by the discovery of ceramic moulds in the ditch of the enclosure and also in some pits. Even fragmented, these remains indicate the making of swords, spearheads, chapes and possibly axes. Eight shell accumulations have been identified in the ditch of the enclosure (Figure 1). 

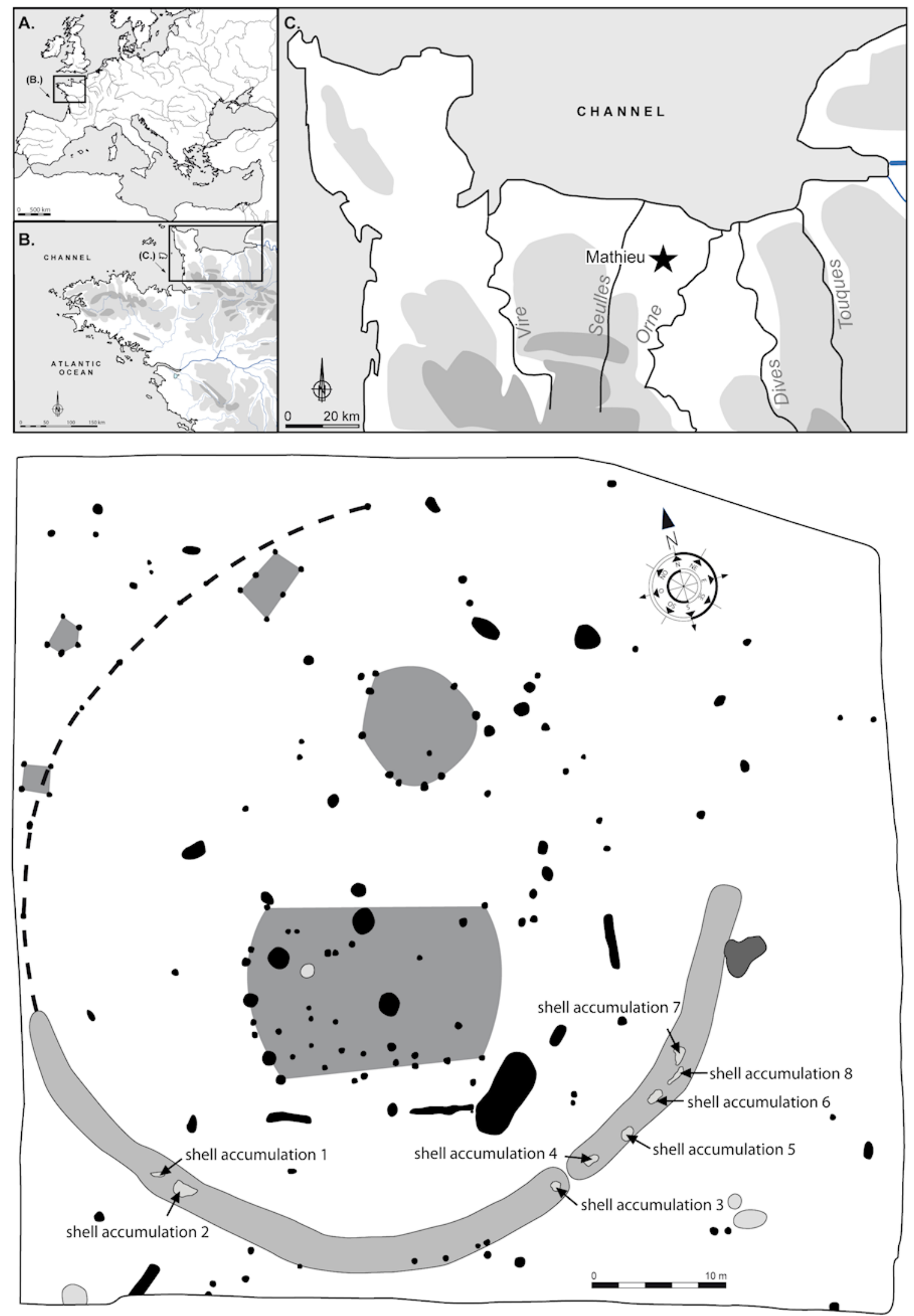

Figure 1: Location and map of the archaeological site of Clos des Châtaigniers at Mathieu. (Image credit: D. Giazzon, L. Quesnel, C. Mougne) 


\section{Methods}

All the information and results presented here have been obtained from sedimentary samples (45 litres in total) collected during the excavation. Sieved with fine meshes ( 4 and $2 \mathrm{~mm}$ ), these samples were sorted and studied at the Archaeosciences Laboratory of the University of Rennes. The identification of marine invertebrates (gastropods, bivalves and sea urchins) was carried out using the comparative collection from the same laboratory (comparative collection Gruet and Dupont, UMR 6566CReAAH), and was confirmed using several reference works on marine biology (Tebble 1966; Poppe and Goto 1991; 1993; Hayward and Ryland1995; Quéro and Vayne 1998; Audibert and Delemarre 2009). The scientific names used for the identified marine molluscs correspond to the international standards of the CLEMAM (2013). Several counting methods were used to calculate the relative proportions of each species. The NISP (Number of Identified Specimens) corresponds to all the identified remains greater than $2 \mathrm{~mm}$. The MNI (Minimum Number of Individuals) was also used. For bivalves, an MNI was obtained after assigning valves to the left or right according to the position of the teeth, the ligament and the pallial sinus line (Dupont 2006a; McCarthy et al. 1999). For spiral gastropods, the MNI is linked to the presence of the peristome (Dupont 2006a). Finally, the remains of each species were weighed (in grams).

The shells were then measured using a digital calliper graduated in millimetres $(\mathrm{mm})(0.01)$ in accordance with the procedures described by Dupont (2006a). Some specific biometrical studies were also performed on the common mussel (Mytilus edulis). Shells found at the site are highly fragmented and consequently the whole length is not measurable. In fact, their fragile nature meant that the shells were found crushed as a result of the mechanical pressure exerted by the overlying sediments. Some authors highlight the fact that a good correlation exists between the height and the length of the shell (Buchanan 1985; Dupont 2006a, 86-87; Campbell 2013) and that it is therefore possible to reconstruct a mussel original size from measurements of shell height. However, mussels discovered at the Clos des Châtaigniers were so fragmented that shell height could not be measured. Therefore, a different method was 
employed, relying on a correlation established between original mussel size and a small part near the teeth (corresponding to the not pearly part, located just after the anterior adductor muscle scar; see Figure 4) (Mougne in prep). Through taphonomic analysis, modifications due to physical and chemical factors on the archaeomalacological material were identified (Claassen 1998; Dupont 2006a; Gutiérrez Zugasti 2008). The associated faunas in the thickness of the shell and in or on the shells were also observed and recorded (Hayward and Ryland 1995).

\section{Results and Discussion}

\subsection{Faunal spectrum}

Thirty species of marine shells (20 bivalves, 10 gastropods), one sea urchin and one crustacean were identified (Figure 2) at the site of Clos des Châtaigniers. Mussels (Mytilus edulis) represent the majority of marine shell remains in all three types of quantification used ( $98 \%$ of the NISP, $75 \%$ of the MNI and $94 \%$ of total weight) (Figure 3 ).

Figure 2. Identified Marine invertebrates at Clos des Châtaigniers (Image credit: C. Mougne) 1: Mytilus edulis $(\mathrm{L}=35 \mathrm{~mm}), 2$ : Acanthocardia tuberculata $(\mathrm{L}=51 \mathrm{~mm}), 3$ : Cerastoderma edule $(\mathrm{L}=$ $27 \mathrm{~mm}), 4$ : Solen marginatus ( $\mathrm{L}=16 \mathrm{~mm}), 5$ : Scrobicularia plana $(\mathrm{L}=16 \mathrm{~mm}), 6$ : Ruditapes decussatus ( $\mathrm{L}=4 \mathrm{~mm}), 7$ : Barnea candida $(\mathrm{L}=13 \mathrm{~mm})$, 8: Macoma balthica $(\mathrm{L}=18 \mathrm{~mm})$, 9: Donax vittatus $(\mathrm{L}=18 \mathrm{~mm}), 10$ : Mactra sp. $(\mathrm{L}=18 \mathrm{~mm}), 11$ : Spisula solida $(\mathrm{L}=33 \mathrm{~mm}), 12$ : Spisula subtruncata $(\mathrm{L}=14 \mathrm{~mm}), 13$ : Ostrea edulis $(\mathrm{L}=25 \mathrm{~mm}), 14:$ Aequipecten opercularis $(\mathrm{L}=8 \mathrm{~mm})$, 15: Mimaclamys varia $(\mathrm{L}=10 \mathrm{~mm}), 16$ : Corbula gibba $(\mathrm{L}=9 \mathrm{~mm}), 17$ : Phaxas pellucidus $(\mathrm{L}=9 \mathrm{~mm})$, 18: Anomia ephippium ( $\mathrm{L}=15 \mathrm{~mm}$ ), 19: Abra sp. ( $\mathrm{L}=4 \mathrm{~mm}), 20$ :Gari sp. (L=6 mm), 21: Gibbula umbilicalis $(\mathrm{L}=13 \mathrm{~mm}), 22$ : Littorina littorea $(\mathrm{L}=22 \mathrm{~mm}), 23$ : Buccinum undatum $(\mathrm{L}=32 \mathrm{~mm})$, 24:Nucella lapillus ( $\mathrm{L}=22 \mathrm{~mm}), 25$ : Nassarius reticulatus $(\mathrm{L}=22 \mathrm{~mm}), 26$ : Ocenebra erinaceus $(\mathrm{L}=34$ $\mathrm{mm}), 27$ : Bela powisiana $(\mathrm{L}=10 \mathrm{~mm}), 28$ : Epitonium clathrus $(\mathrm{L}=10 \mathrm{~mm}), 29$ : Lacuna pallidula $(\mathrm{L}=7$ $\mathrm{mm}), 30$ : Littorina obtusata $(\mathrm{L}=7 \mathrm{~mm}), 31$ : Test of urchin $(\mathrm{L}=6 \mathrm{~mm}) 32$ : Balanus sp. $(\mathrm{L}=11 \mathrm{~mm})$. 


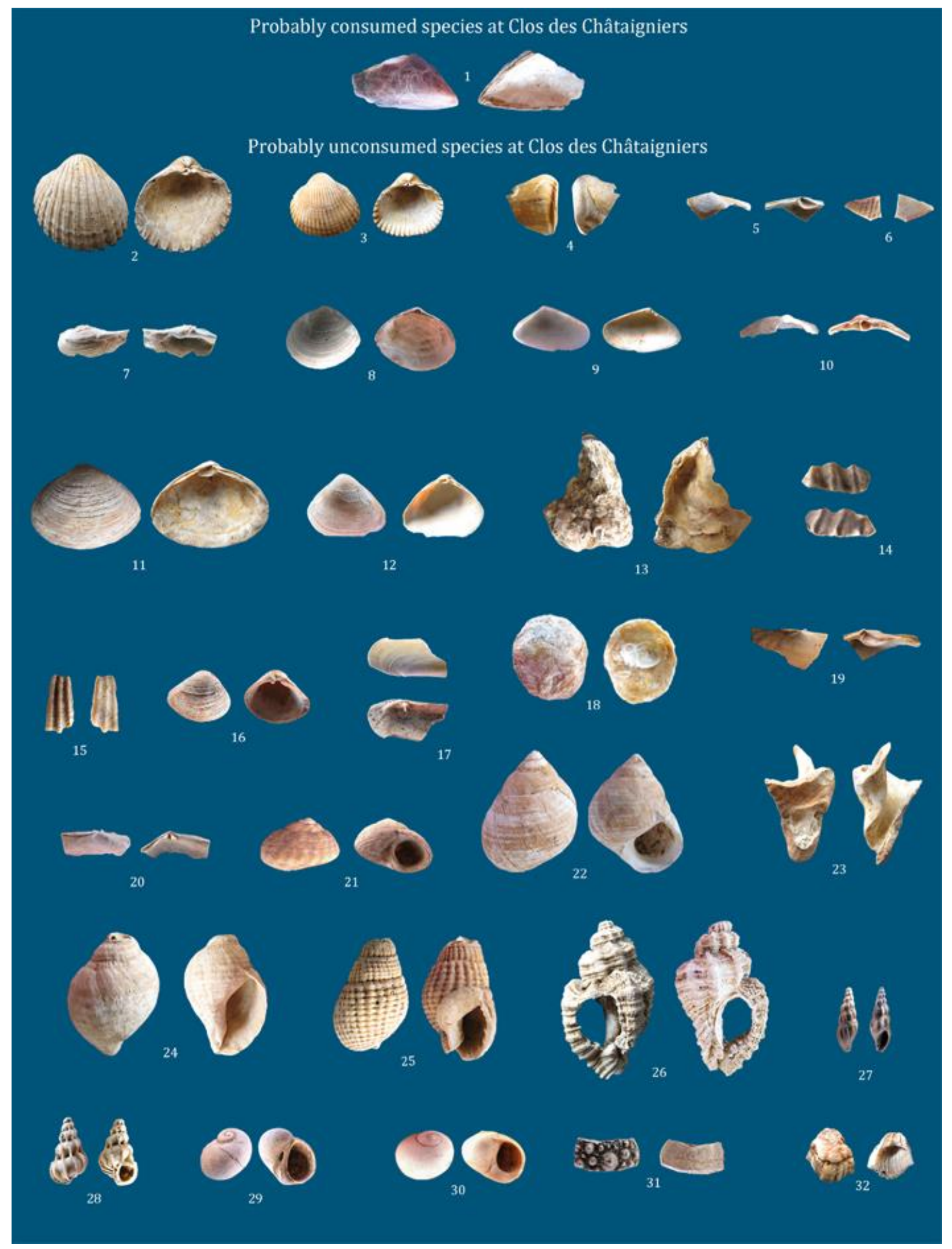


The high percentage of NISP for this species is linked to high levels of fragmentation. As a consequence, the relation between the Number of Identified Specimens and the Minimum Number of Individuals (221752/1490) shows that, for a single mussel individual, 149 remains were counted. It is thus often difficult to obtain total lengths and to describe the collecting strategies. From these correlations between total length and a small part near the teeth, 214 total lengths ( RV = 105; LV = 109) have been reconstructed. These measurements ranged between 27 and $65 \mathrm{~mm}$, with a mean of $43.5 \mathrm{~mm}$, corresponding to adult individuals (Figure 4).

\begin{tabular}{|c|c|c|c|c|}
\hline Latin name & Common name & NISP & MNI & Weight (g) \\
\hline \multicolumn{5}{|l|}{ Bivalves } \\
\hline Mytilus edulis & common mussel & 221752 & 1490 & 6188.24 \\
\hline Ostrea edulis & flat oyster & 33 & 4 & 5.81 \\
\hline Anomia ephippium & saddle oyster & 1 & 1 & 0.18 \\
\hline Aequipecten opercularis & queen scallop & 1 & 1 & 0.01 \\
\hline Mimachlamys varia & fan scallop & 3 & 1 & 0.08 \\
\hline Solen marginatus & grooved razor shell & 10 & 4 & 1.96 \\
\hline Phaxas pellucidus & & 7 & 5 & 0.04 \\
\hline Acanthocardia tuberculata & & 2 & 2 & 19.19 \\
\hline Acanthocardia sp. & & 115 & 3 & 16.48 \\
\hline
\end{tabular}




\begin{tabular}{|c|c|c|c|c|}
\hline Cerastoderma edule & common cockle & 107 & 16 & 12.65 \\
\hline Cerastoderma sp. & cockle & 186 & 8 & 110.47 \\
\hline Barnea candida & & 669 & 36 & 11.8 \\
\hline Donax vittatus & beam clam & 1 & 1 & 0.36 \\
\hline Donax sp. & beam clam & 275 & 25 & 4.64 \\
\hline Gari sp. & & 10 & 3 & 0.11 \\
\hline Macoma balthica & & 86 & 33 & 5.05 \\
\hline Mactra sp. & & 29 & 11 & 0.88 \\
\hline Spisula solida & Atlantic surf clam & 1 & 1 & 2.21 \\
\hline Spisula subtruncata & & 1 & 1 & 0.03 \\
\hline Spisula sp. & & 131 & 54 & 1.92 \\
\hline Scrobicularia plana & peppery furrow shell & 149 & 4 & 4.09 \\
\hline Abra sp. & & 39 & 25 & 0.24 \\
\hline Corbula gibba & & 22 & 8 & 0.68 \\
\hline Ruditapes decussatus & European carpet clam & 1 & 1 & 0.08 \\
\hline Cardiidae & & 22 & & 0.71 \\
\hline Mactridae & & 891 & 7 & 5.83 \\
\hline
\end{tabular}




\begin{tabular}{|c|c|c|c|c|}
\hline Pectinidae & & 2 & & 0.03 \\
\hline Semelidae & & 278 & & 3.21 \\
\hline Tellinidae & & 188 & & 1.8 \\
\hline Veneroida & & 549 & & 4.51 \\
\hline \multicolumn{5}{|l|}{ Gastropods } \\
\hline Littorina littorea & common periwinkle & 336 & 123 & 123.78 \\
\hline Littorina obtusata & flat periwinkle & 18 & 11 & 1.53 \\
\hline Littorina sp. & & 44 & 41 & 0.55 \\
\hline Lacuna pallidula & pale lacuna & 1 & 1 & 0.12 \\
\hline Gibbula umbilicalis & flat top shell & 16 & 13 & 6.54 \\
\hline Gibbula sp. & top shell & 48 & 3 & 1.77 \\
\hline Buccinum undatum & common whelk & 4 & 2 & 4.77 \\
\hline Nassarius reticulatus & netted dog whelk & 27 & 5 & 5.21 \\
\hline Nassarius sp. & & 5 & 2 & 0.19 \\
\hline Nucella lapillus & dogwhelk & 57 & 20 & 39.01 \\
\hline Ocenebra erinaceus & sting winkle & 28 & 6 & 6.39 \\
\hline Bela powisiana & & 1 & 1 & 0.04 \\
\hline
\end{tabular}




\begin{tabular}{|l|l|l|l|l|}
\hline Epitonium clathrus & common wentletrap & 1 & 1 & 0.1 \\
\hline Unspecified gastropods & & 19 & 1.12 \\
\hline Unspectified molluscs & & 15 & & 0.22 \\
\hline Marine Molluscs total & & 226181 & 1974 & $\mathbf{6 5 9 4 . 6 3}$ \\
\hline Balanus sp. & barnacle & 35566 & 5927 & 187.39 \\
\hline Crustacean total & & $\mathbf{3 5 5 6 6}$ & $\mathbf{5 9 2 7}$ & $\mathbf{1 8 7 . 3 9}$ \\
\hline Echinoderm total & urchin & $\mathbf{2}$ & $\mathbf{1}$ & $\mathbf{0 . 0 3}$ \\
\hline Unspecified urchin & & & 0.03 \\
\hline
\end{tabular}




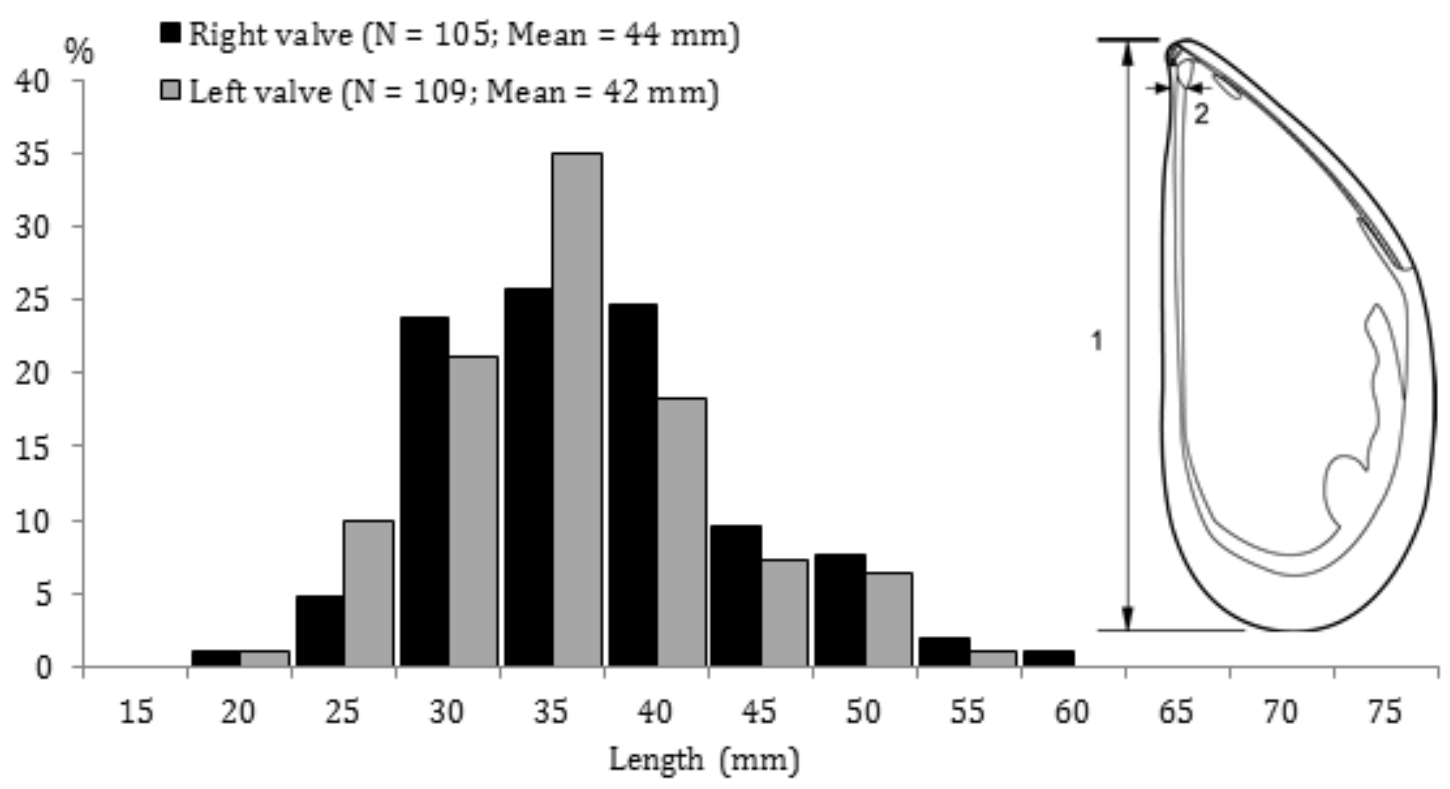

Figure 4: Distribution of reconstructed length (1) classes $(\mathrm{mm})$ of Mytilus edulis, from a small part near the teeth (2). ( $\mathrm{N}=$ number of valves) (Image credit (mussel): L. Quesnel)

Seven other identified marine shells are edible and may have been part of the diet of the inhabitants of Clos des Châtaigniers: Littorina littorea, Barnea candida, Macoma balthica, Donax sp., Abra sp., Spisula sp. and Cerastoderma sp. (Figure 3). Nonetheless, the shells of these bivalves measured less than $20 \mathrm{~mm}$, a size typically rejected as being too small for human consumption. Thus the presence of these six species does not appear to be linked to human diet. The dogwhelk (Nucella lapillus) is represented by 20 medium-sized individuals (between 20 and $40 \mathrm{~mm}$ ). Half of them, however, show marks of marine worms of Polydora-type in their internal shell. These taphonomic modifications show that specimens of dogwhelk arrived dead and empty, without flesh, to the site. Twentyone other species (Anomia ephippium, Ostrea edulis, Solen marginatus, Acanthocardia tuberculata, Scrobicularia plana, Spisula solida, Buccinum undatum, Aequipecten opercularis, Mimachlamys varia, Ruditapes decussatus, Gari sp., Phaxas pellucidus, Lacuna pallidula, Littorina obtusata, Bela powisiana, Nassarius reticulatus, Epitonium clathrus, Corbula gibba, Ocenebra erinaceus, Mactra sp. and Gibbula sp.) are represented by only 1 to 13 individuals (Figure 3 ). The small quantities of these marine invertebrates are unlikely to indicate intentional collecting for human consumption. In addition, some of these species are small in size and evidence shows that deposited specimens were already dead when they arrived at the site. Only one fragment of sea urchin, species 
unidentified, was found (Figure 2, 31). Finally, some barnacles, belonging to the order of Cirripedia crustaceans, were observed (Figure 2, 32) and probably brought to the site during the transport of the mussels.

In summary, the size and quantity of mussel remains show that this shellfish was consumed by past inhabitants. However, the consumption of the other thirty-one identified marine invertebrates cannot be proved because of their presence in small quantities (Figure 3 ), small sizes and/or observed taphonomic modifications.

\subsection{Gathering area}

The site of Clos des Châtaigniers is located $10 \mathrm{~km}$ from the Channel coast. The gathering strategies reflected the values attributed to each species (e.g. flavour), and other environmental parameters such as accessibility and abundance at the seashore. The inhabitants seem to have exploited mainly rocky to muddy/rocky shores ( $84 \%$ of the MNI of marine shells) (Figure 5). This is evidenced by the numerical dominance of the mussel, the most frequently consumed shellfish on the site, which lives in the intertidal zone, down to $10 \mathrm{~m}$ in depth along the coast. Mussel gathering is quite straightforward since these are readily visible and can be collected by hand or with a tool to cut the byssus, in clusters or individually. Mussels can be consumed all year round but are fleshier during the reproductive period, between March and October (Poppe and Goto 1993). Those mussels living in sandy to muddy/sandy shore substrates were more rarely exploited ( $11 \%$ of the MNI) (Figure 5 ). It is interesting to note that the spectrum of species coming only from sandy to muddy/sandy environment mostly consists of small individuals, with a shell size smaller than 20mm (Donax sp., Spisula sp., Abra sp., Macoma balthica). 
Figure 5: Tide range and substrates of the marine species (shaded cell = potential presence; $+=$ present; $(+)=$ more rarely present; after Dupont 2006a).

Tidal range

Species

Substrate

Intertidal

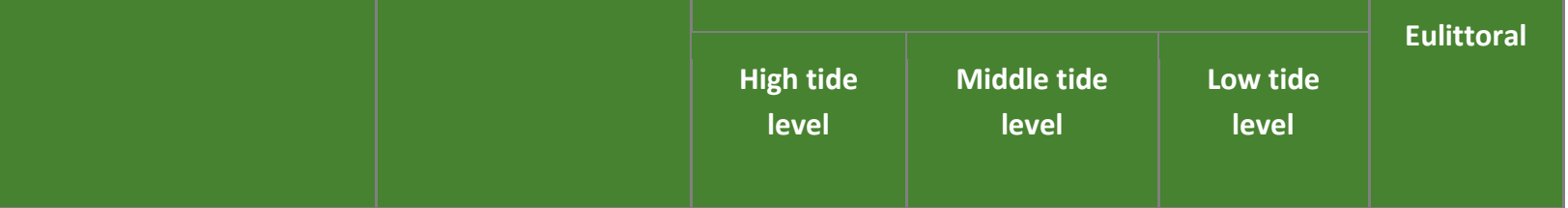

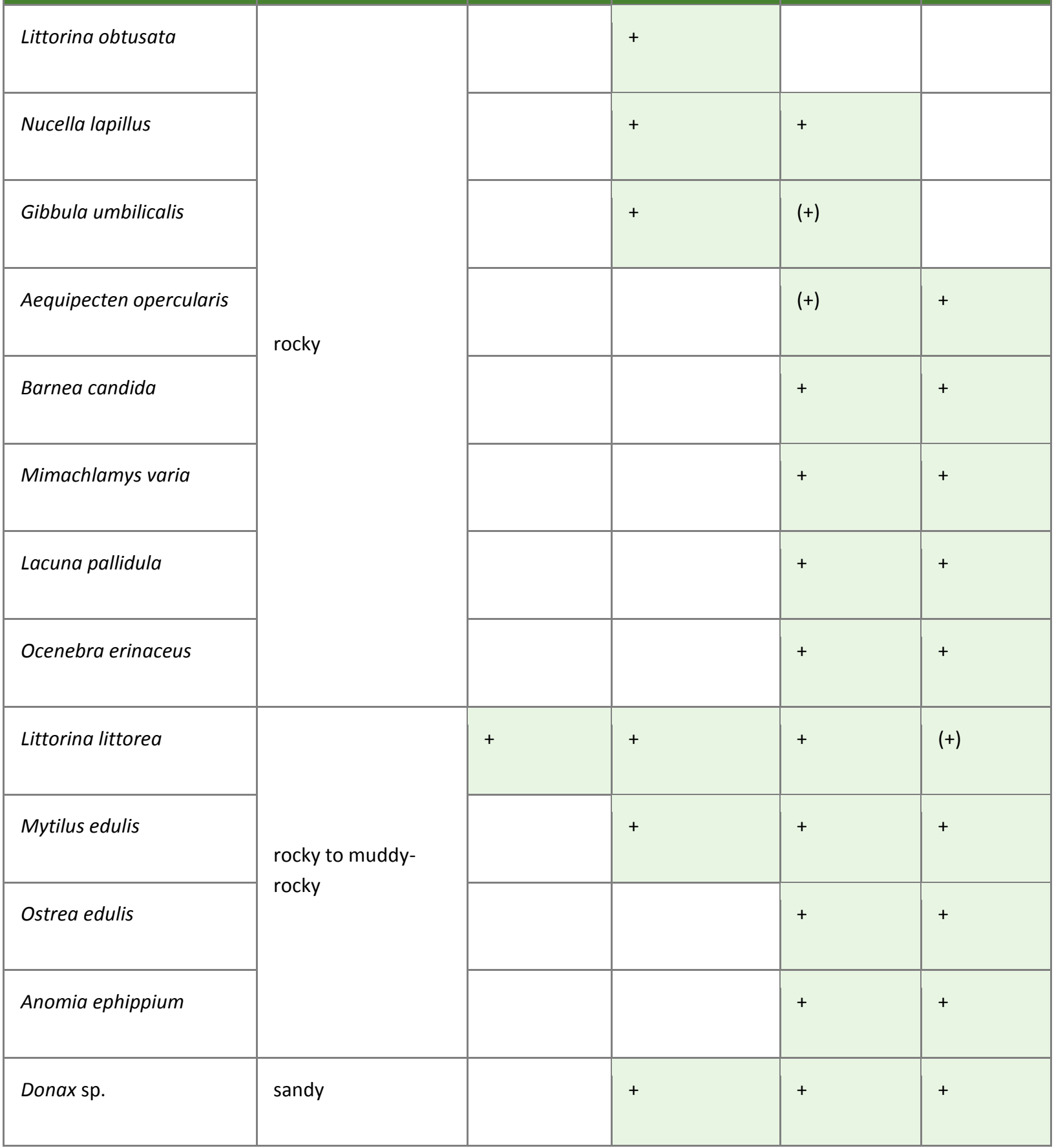




\begin{tabular}{|c|c|c|c|c|}
\hline $\begin{array}{l}\text { Acanthocardia } \\
\text { tuberculata }\end{array}$ & & & $(+)$ & + \\
\hline Spisula solida & & & + & + \\
\hline Spisula sp. & & & + & + \\
\hline Donax vittatus & & & + & + \\
\hline Mactra sp. & & & + & + \\
\hline Bela powisiana & & & + & + \\
\hline Spisula subtruncata & & & & + \\
\hline Corbula gibba & & & & + \\
\hline Macoma balthica & & $(+)$ & + & + \\
\hline Ruditapes decussatus & & + & + & + \\
\hline Nassarius reticulatus & & + & + & + \\
\hline Cerastoderma edule & & + & + & + \\
\hline Abra sp. & $\begin{array}{l}\text { sandy to muddy- } \\
\text { sandy }\end{array}$ & + & + & + \\
\hline Gari sp. & & & + & + \\
\hline Buccinum undatum & & & + & + \\
\hline Solen marginatus & & & + & + \\
\hline Phaxas pellucidus & & & $(+)$ & + \\
\hline
\end{tabular}




\begin{tabular}{|l|l|l|l|l|l|}
\hline Epitonium clathrus & & & & & + \\
\hline Scrobicularia plana & muddy & $(+)$ & + & + & $(+)$ \\
\hline
\end{tabular}

\subsection{From gathering to consumption}

After being gathered, the shells were then transported to the site of Clos des Châtaigniers. Transport may have either been by boat, given that the River Orne was navigable during protohistory, or by land. The return trip would have taken at least a half-day. The large number of barnacles $(5,927$ specimens) and small shells found in shell deposits seem to indicate that the preparation of the shells was probably done on the site. The barnacles were probably attached to the mussels and transported with them. It is likely that some of the barnacles detached from the mussels during the preparation or preservation phases. Traces of burning are evident on some mussels, representing on average $87 \%$ of NISP of the mussels. These marks are perhaps related to cooking methods or secondary activities occurring after consumption. Archaeological studies of burnt shell remains are not numerous in the archaeological literature. For this reason, we undertook research on the methods of cooking mussels and their effects on the shell, as described in the ethnohistorical literature, in order to gain some information (Waselkov 1987). Mussels can be cooked by placing them in the heart of a fire, in a steam oven (Best 1924, 417; Greengo 1952, 77; Duguet 1995, 367; Kroeber and Barrett 1960, 113; Meehan 1977, 366; Waselkov 1987, 101-2), placing them on hot stones (Terrell $\underline{1967}, 44$; Oberg $\underline{1973}, 67$ ) or roasting them around fires (Waselkov 1987, 101). Other hypotheses could also explain the high rate of burned archaeological mussels. After the mussels had been eaten, the shells could have been thrown into a fire. The shells could also have been used eventually to maintain the fire, or even to put it out. This activity could reflect hygienic and/or marine waste management strategies. Nevertheless, it is difficult to select one of these possibilities given the lack of available bibliographical references. However, experimentation on shell material could make it possible to identify specific criteria for each type of cooking method, as has already been 
undertaken for bones (Costamagno et al. 2010; Lebon 2010;

Zazzo 2010). The results obtained would provide some real answers regarding cooking methods and heat treatments and seems a promising area for future studies.

The collected shellfish were either eaten directly or processed for later consumption. There are several different ways to preserve mussel flesh: it can be dried in the sun (with or without the shell), smoked and stored in jars, in baskets or strung on suspension lines and later rehydrated and boiled (Gifford 1939, 315; Greengo 1952, 77-78; Stewart 1943, 60; Kroeber and Barrett 1960, 113; Oberg 1973, 67; Aschmann 1975, 46; Best 1924, 417; Waselkov 1987, 106-7).

Previous research demonstrated, through experimental archaeology, that it was possible to dry a very large number of mussels in a relatively short period of time, with minimum effort, and using simple technology (Henshilwood et al. 1994). The most effective experiments in terms of time/calories related to the cooking and drying of mussel flesh inside the shell. Once cooked and dried, the flesh can be easily removed from the shell in only two or three seconds, so that fewer people and less time are needed to process large quantities of mussels. This method also reduces the need for firewood, since the mussels are cooked within around seven minutes. This technique eliminates the need for drying frames or posts and suspended lines, and minimises labour input (Henshilwood et al. 1994).

Finally, the dehydrated shellfish were generally later plunged into fresh water, and then boiled (Gifford 1939, 315; Swanton 1946, 378; Greengo 1952, 77-78; Kroeber and Barrett 1960, 113). For example, some North American populations living close to the sea in temperate areas kept dried shellfish all year round, either for exchange or for their own consumption (Greengo 1952, 78-80; Oberg 1973, 67-75).

Nevertheless, we lack the archaeological data (organic residues in pottery, artefacts linked with preservation such as baskets, etc.) to state definitely that such a preservation technique was used at the site of Clos des Châtaigniers. 


\subsection{Spatial distribution of archaeological remains}

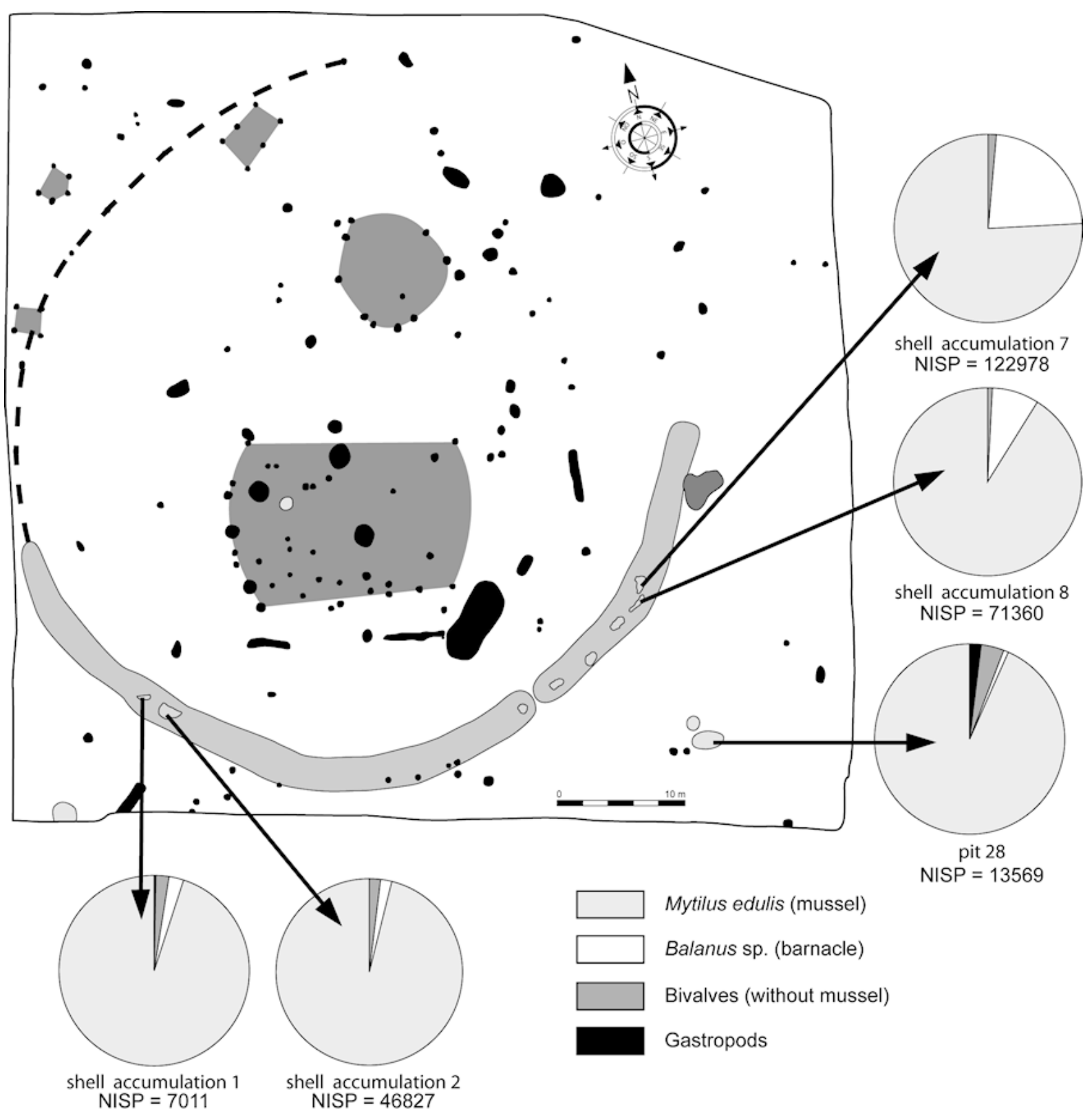

Figure 6: Spatial distribution of the marine invertebrates from the percentage of the NISP. (Image credit: D. Giazzon, L. Quesnel, C. Mougne)

The distribution of the shell accumulations seems to be confined to specific areas within the enclosure. Shells have only been found inside the ditch of this enclosure and in a single outside pit (F28) (Figure 1 and Figure 6). Four sedimentary samples have been extracted from inside this ditch (accumulations 1, 2, 7 and 8) and one in pit 28 (Figure 6). The quantification used for this distribution is the NISP expressed as a 
percentage. Inside the pit, accumulations and the percentage of mussel NISP are quite similar, demonstrating that this mussel was consumed in different parts of the site (Figure 6). The distribution of Balanus sp., however, shows an important difference. Barnacles represent between 1 and $2 \%$ of the NISP in pit 28 and in accumulations 1 and 2, as opposed to $8.5 \%$ in accumulation 8 and $23 \%$ in accumulation 7 (Figure 6 ). These barnacles, found in large quantities, might have become detached when the mussels were prepared or cooked, as previously mentioned. Considering the large quantities of barnacles, the preparation, cleaning and cooking of this shellfish could have taken place at the site, and perhaps in an area close to accumulations 7 and 8 (Figure 6).

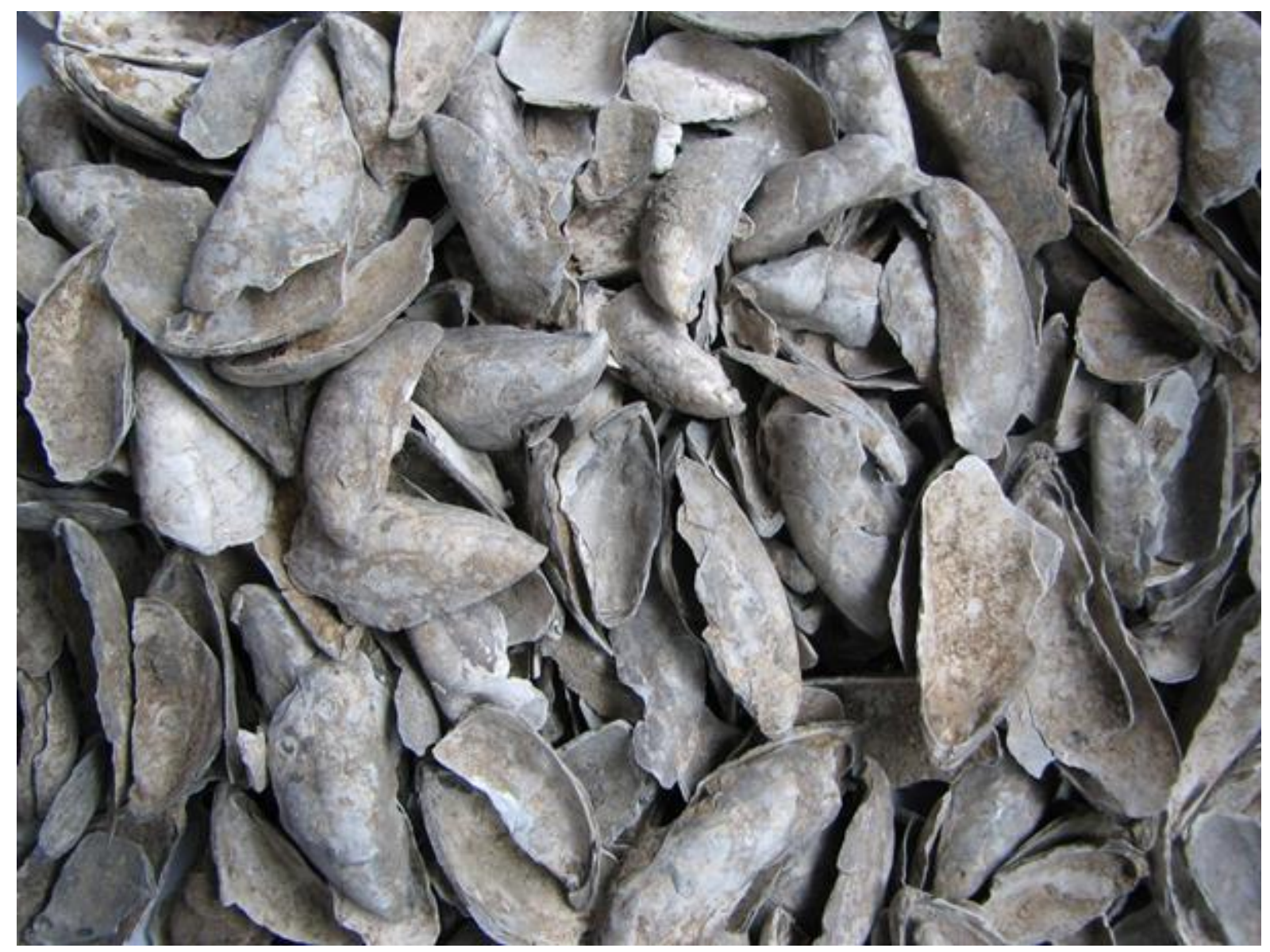

Figure 7: Traces of burning on left valves of mussels (Mytilus edulis) in the shell accumulation no.7. (Image credit: C. Mougne)

Burnt shell remains represent $60 \%$ of the total NISP and $87 \%$ of mussel NISP (Figure 7). The distribution of these remains is, however, heterogeneous at the site. The percentage of burnt mussel remains is 
significantly higher in the ditch of the enclosure (between 35 and $88 \%$ of the NISP) than at pit $28(1.5 \%$ of the NISP) (Figure 8$)$. This seems to indicate either a spatial organisation of the burnt mussel remains or differential treatment of the shells during or after their cooking.

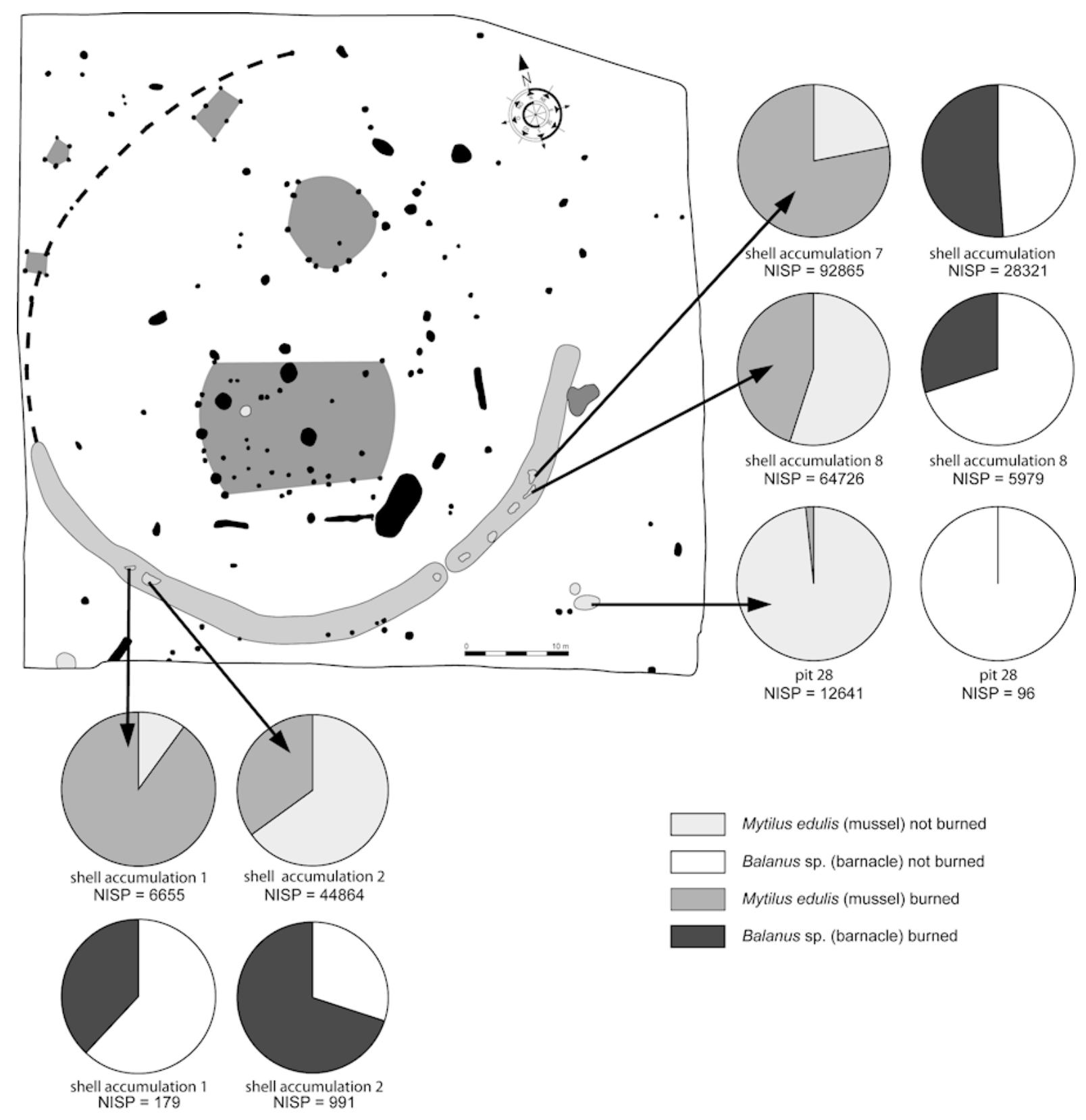

Figure 8: Spectrum of the burned or unburned remains of mussels and barnacles by shell accumulations in percentage of the NISP. (Image credit: D. Giazzon, L. Quesnel, C. Mougne) 


\subsection{The presence of marine shells as an indicator of the consumption of fish?}

Numerous small marine shells (smaller than $11 \mathrm{~mm}$ ) have been found at the site. These remains are not burnt, unlike the great majority of mussels with which they were mixed in the ditch of the enclosure and in the pit (Figure 9). These shells do not seem to have been consumed by past humans (see section 4.1). In order to understand the origin of these shell fragments, they have been compared with other remains from modern mussel-beds. Bronze Age populations could have accidentally transported these small shell remains fixed to and mixed with collected mussels. Mussels originating from four modern-day coastal areas (Sangette, Nord-Pas-de-Calais; Saint-Honorine-des-Pertes, BasseNormandie; Quiberon, Brittany and Lérat, Pays-de-La-Loire) located at the Channel and Atlantic coasts have been collected. These mussels were cleaned in a strainer and associated shell remains compared with archaeological remains. Fragment sizes in modern mussels vary (between 2 and $20 \mathrm{~mm}$ ) and these fragments show rounded outlines caused by marine erosion. By contrast, the sizes of archaeological remains identified at Clos des Châtaigniers are more uniform (between 5 and $10 \mathrm{~mm}$ ), and show angular and regular breaks. 


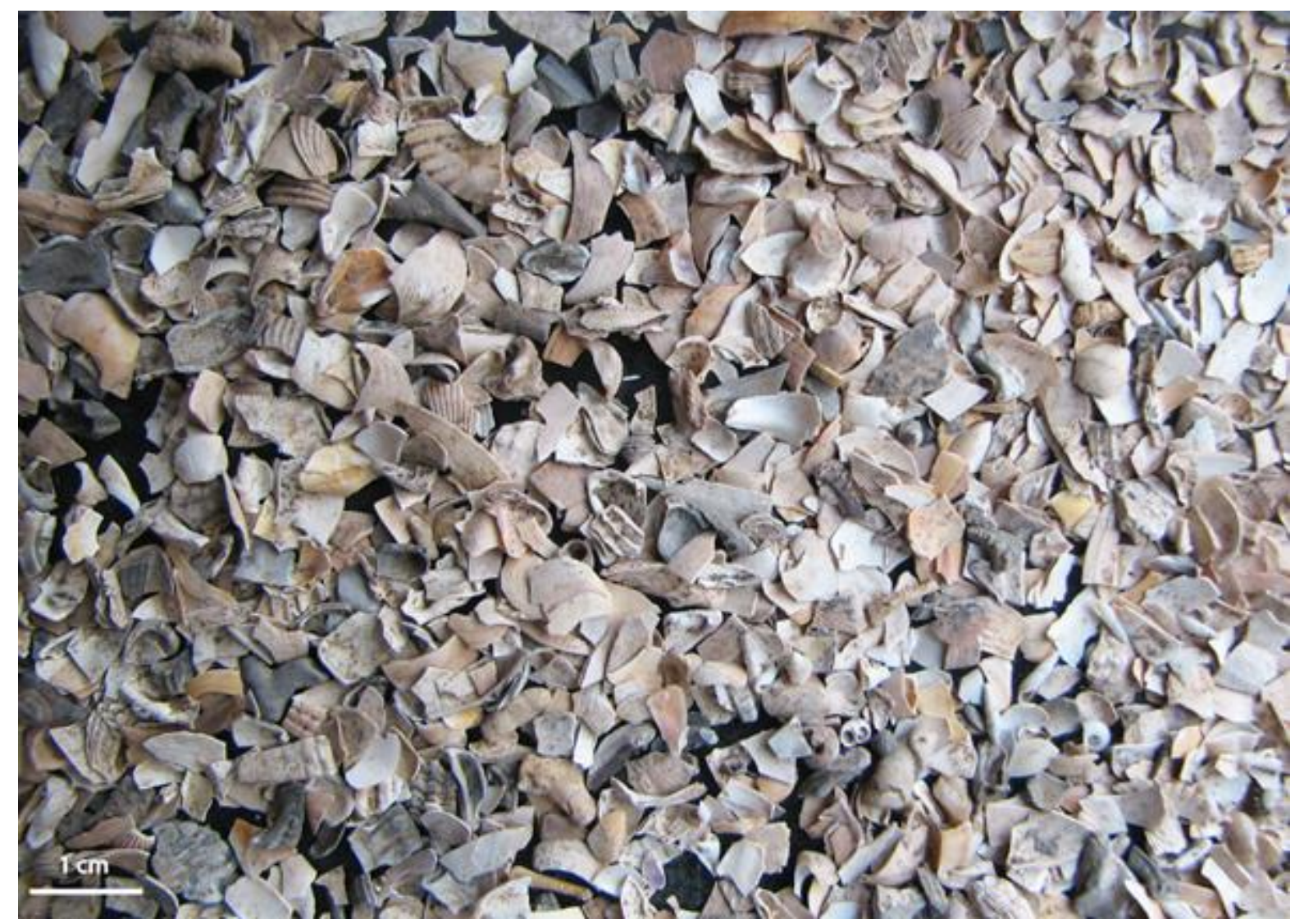

Figure 9: Shell remains in accumulation no.7. (Image credit: C. Mougne)

Identified shell species (Barnea candida, Donax sp., Macoma balthica, Spisula sp. and Abra sp.) and those fragmented shells measuring between 5 and $10 \mathrm{~mm}$ could correspond to residues from the stomach contents of fish. The fish would have been gutted and the entrails discarded by the inhabitants, together with any shellfish remains. Several fish species eaten by humans have a diet that includes shellfish, such as European eel (Anguilla anguilla), conger (Conger conger), plaice (Glyptocephalus cynoglossus), Ballan wrasse (Labrus bergylta), haddock (Melanogrammus aeglefinus), hake (Merluccius merluccius), sole (Solea solea), gilthead bream (Sparus aurata), turbot (Psetta maxima), pollack (Pollachius pollachius) or dogfish (Scyliorhinus sp.) (Figure 10) (Muus et al. 2005; Teletchea 2009). One should bear in mind that the presence of such remains could also result from the accumulation of dead aquatic birds or from faecal waste (Erlandson and Moss 2001; Van Leeuwen 2012). Thus, shell remains could also originate from animal stomach contents. It is important to note here that remains of three unidentified fish and one bird have been discovered at Clos des Châtaigniers. 
Figure 10: Examples of fishes present in Normandy nowadays, consumed by men and who have a diet based partially on marine shells (+: consumption of marine shellfish; Muus et al. 2005; Teletchea 2009).

\begin{tabular}{|c|c|c|}
\hline Anguilla anguilla & European eel & + \\
\hline Conger conger & European conger & + \\
\hline Cyclopterus lumpus & Lumpfish & + \\
\hline Diplodus sargus & Sargo & + \\
\hline Diplodus vulgaris & & + \\
\hline Gadus morhua & Atlantic cod & + \\
\hline Glyptocephalus cynoglossus & Plaice & bivalves \\
\hline Hypotremata sp. & Ray & mostly mussels \\
\hline Labrus bergylta & Ballan wrasse & + \\
\hline Limanda limanda & Common dab & gastropods and bivalves \\
\hline Melanogrammus aeglefinus & Haddock & + \\
\hline Merluccius merluccius & European hake & + \\
\hline Microstomus kitt & Lemon sole & mussels \\
\hline Molva molva & Common ling & + \\
\hline Pagellus erythrinus & Common pandora & + \\
\hline
\end{tabular}




\begin{tabular}{|c|c|c|}
\hline Pagrus pagrus & Red porgy & + \\
\hline Pegusa lascaris & Sand sole & + \\
\hline Platychthys flesus & European flounder & mussels \\
\hline Pleuronectes platessa & European plaice & bivalves with thin shells \\
\hline Pollachius pollachius & Pollack & + \\
\hline Psetta maxima & Turbot & bivalves \\
\hline Scyliorhinus canicula & Small-spotted catshark & + \\
\hline Scyliorhinus stellaris & Nursehound & + \\
\hline Scorpaena scrofa & Red scorpionfish & + \\
\hline Solea solea & Common sole & bivalves with thin shells \\
\hline Sparus aurata & Gilt-head bream & mostly bivalves \\
\hline Trisopterus luscus & Pouting & small bivalves \\
\hline
\end{tabular}

Analysis of bivalves other than mussels allowed us to understand the distribution of these small shells within the settlement (Figure 11). Pit 28 is unique, with a strong presence of Semelidae ( $44 \%$ of the NISP) while Tellinacea is almost absent ( $3 \%$ of the NISP). The distribution of Tellinacea, Pholadidae, Mactridae and Cardiidae is uniform in the ditch of the enclosure. By contrast, Semelidae are totally absent from accumulation 1 . This distribution could potentially correspond to the preparation of fish or birds that have different diets. 


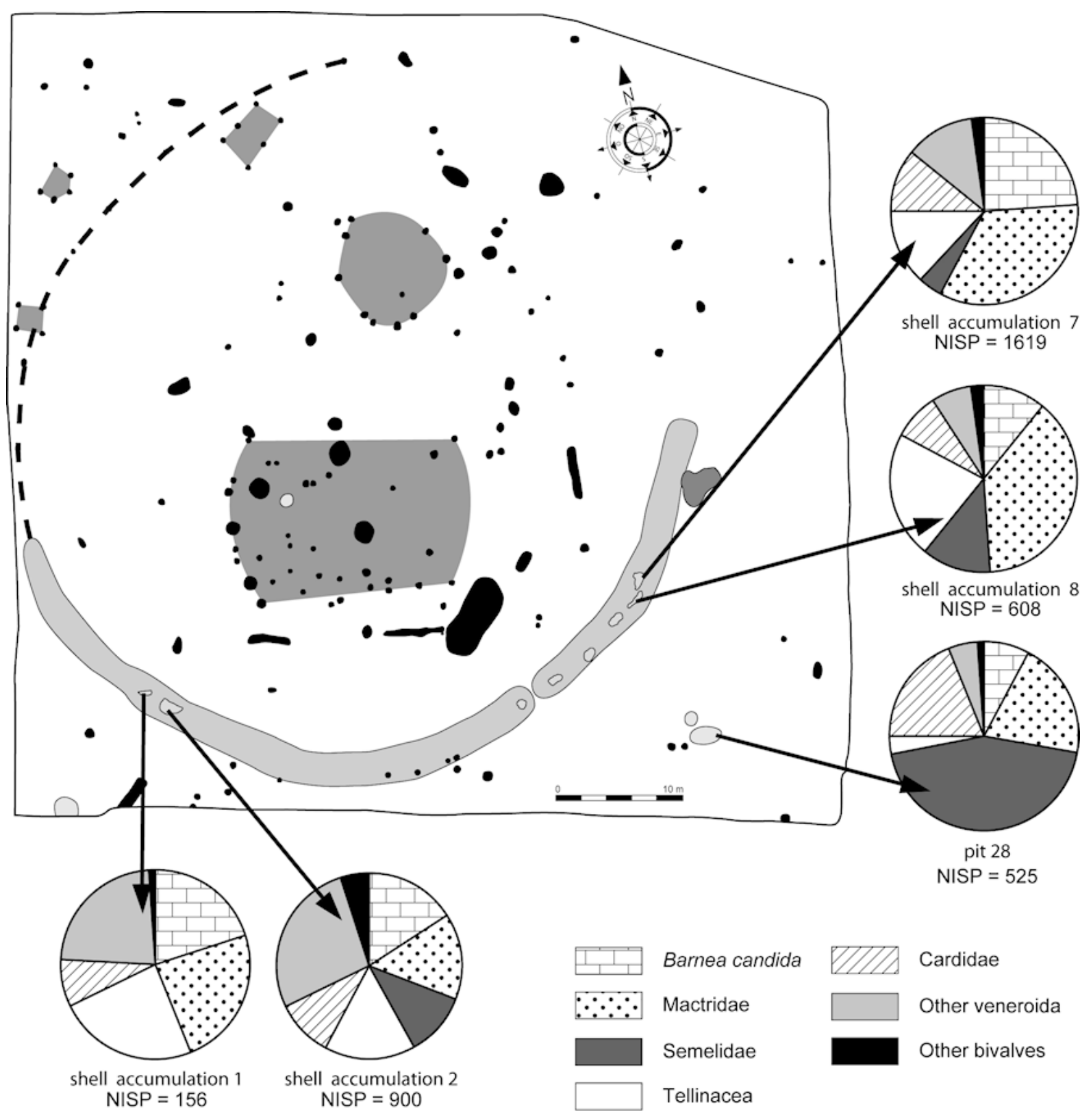

Figure 11. Spectrum of the bivalve remains (excepted the mussels) by shell accumulations. (Image credit: D. Giazzon, L. Quesnel, C. Mougne) 


\begin{tabular}{|c|c|c|c|}
\hline Order & Family & Genus & Species \\
\hline \multirow{9}{*}{ Veneroida } & Pholadidae & Barnea & candida \\
\hline & \multirow{2}{*}{ Mactridae } & Spisula & sp. \\
\hline & & Mactra & sp. \\
\hline & \multirow{2}{*}{ Semelidae } & Abra & sp. \\
\hline & & Scrobicularia & plana \\
\hline & \multirow{2}{*}{ Tellinacea } & Donax & sp. \\
\hline & & Macoma & balthica \\
\hline & \multirow{2}{*}{ Cardiidae } & Cerastoderma & sp. \\
\hline & & Acanthocardia & sp. \\
\hline
\end{tabular}

Theodoropoulou $(2007,178)$ points out that, on some archaeological sites, small-sized marine shells could originate from stomach contents of mammals and aquatic birds or fish. However, she highlights the fact that it is very difficult to establish such an origin given the lack of reference studies. Van Neer and Pieters (1997) mentioned that, in a 15th-century coastal village in Belgium, remains of plaice (Pleuronectes platessa, 130 individuals) have been discovered in association with bean clam shells (Donax vittatus), interpreted as the stomach contents of these fish. Likewise, in waste areas of the medieval castle of Boves (Somme), all the identified marine shells ( 8 at species level and 9 at genus level) originate from the preparation of fish used in human diet (Dupont 2005). 
In order to answer this type of interrogation more precisely, it would be interesting to propose some criteria for the identification of aquatic animals from their stomach contents, through the development of studies and bibliographical research on the diet of these faunas. The results could demonstrate the consumption of other aquatic animals, whose skeletal remains were not preserved, marine shells being the only indicators of their initial presence.

\section{Conclusion}

In conclusion, the archaeomalacological study shows that the shell remains discovered at Clos des Châtaigniers represent mainly food waste. Despite the size and the diversity of the samples, mussels seem to have been the only shellfish to have really played a role in the diet of local inhabitants during the Bronze Age. The choice of this shellfish can be explained as a result of easy access and abundance at the coastline of Normandy. Other marine invertebrates may have been brought to the site during the transport of mussels or represent the collection of empty shells. The study also reveals the consumption of other marine animals such as fish or birds, whose stomach contents contained small amounts of shells. The site is characterised by high numbers of mussels with medium to large sizes. Gathered in a rocky or muddy/rocky environment, they were then transported $10 \mathrm{~km}$ inland. The absence of small-sized specimens of mussels might indicate prior selection during collection at the seashore. This sorting would reduce the number of mussels to be transported, thus less effort was required. The presence of numerous barnacles may signify that the mussels were washed and prepared at the site of Clos des Châtaigniers. The high ratio of burnt mussel remains at the site could be associated with a particular cooking method or the management of marine waste.

The presence of common mussels (Mytilus edulis) is frequent in protohistorical sites in Normandy (Dupont 2006b; Mougne and Dupont 2012; Mougne et al. 2013; Mougne in prep). Therefore, the consumption of mussels at the site of Clos des Châtaigniers is not an isolated phenomenon but corresponds to an activity practiced in Normandy during the Bronze and Iron Ages. 


\section{Acknowledgements}

We would like to specially thank Yves Gruet for his assistance in identifying specimens and for reading this article.

\section{Bibliography}

Aschmann, H. 1975 'Culturally determined recognition of food resource in the coastal zone', Geoscience and Man 12, 43-47.

Audibert, C. and Delemarre, J.-L. 2009 Guide des coquillages de France, Atlantique et Manche, Paris: Belin.

Best, E. 1924 The Māori (2 volumes): Memoirs of the Polynesian Society, Wellington: Harry $\mathrm{H}$. Tombs.

Buchanan, W.F. 1985 'Middens and mussels: an archaeological enquiry', South African Journal of Sciences 81, 15-16.

Çakirlar, C. 2009 Mollusk shells in Troia, Yenibademli, and Ulucak: an archaeomalacological approach to the environment and economy of the Aegean, Brit. Archaeol. Rep. Int. Ser. 2051, Oxford: Archaeopress.

Campbell, G.E. 2013 'Size prediction in archaeomalacology: the common mussel, Mytilus edulis L., as an example', Archaeological and Anthropological Sciences. http://dx.doi.org/10.1007/s12520-013-0155-2

Claassen, C. 1998 Shells, Cambridge Manuals in Archaeology, Cambridge: Cambridge University Press.

CLEMAM 2013 'Checklist of European marine mollusca', http://www.mnhn.fr/base/malaco.html Last accessed 15 November 2013. 
Costamagno S., Théry-Parisot I., Kuntz D., Bon Fr., Mensan R. 2010 'Impact taphonomique d'une combustion prolongée sur des ossements utilisés comme combustible' in Théry-Parisot I., Chabal L., and Costamagno S. (eds) Taphonomie de la combustion des résidus organiques et des structures de combustion en contexte archéologique, Actes de la table ronde, 27-29 mai 2008, CEPAM, P@lethnologie 2. 173187. http://www.palethnologie.org/category/2010-2/

Duguet, J. 1995 'L'origine des mots chaudrée, éclade et terée', Roccafortis: Bulletin de la Société de Géographie de Rochefort 3e série, 2(16), 362-67.

Dupont, C. 2005 'L'étude des coquillages de Boves ou la description des contenus stomacaux de poissons (Somme)', Unpublished report.

Dupont, C. 2006a La malacofaune de sites mésolithiques et néolithiques de la façade atlantique de la France: Contribution à l'économie et à l'identité culturelle des groupes concernés, Brit. Archaeol. Rep. Int. Ser. 1571, Oxford: Archaeopress.

Dupont, C. 2006b 'Etude archéozoologique: la faune marine, coquillages et crustacés de la phase $3^{\prime}$ in V. Carpentier, E. Ghesquiere and C. Marcigny (eds) Grains de sel. Sel et salines du littoral bas-normand (Préhistoire - XIXe siècle), entre Archéologie et Histoire, CeRAA/Amarai. 111-16.

Dupont, C. 2008 'La malacofaune marine de Tariec vraz (Landéda, Finistère)' in Y. Pailler and Y. Sparfel (eds)Rapport de sondage d'urgence sur un site de l'âge du Bronze ancien, Ile Tariec vraz en Landéda (Finistère), SRA Bretagne, Rennes. 25-26.

Dupont, C. 2011 'Les données malacologique: du dépôt alimentaire à la parure' in S. Vacher (ed) Le complexe cultuel à enclos fossoyés de La Vaurie à Périgny, Rapport final d'opération INRAP, Unpublished report, SRA Poitou-Charentes, Poitiers. 200-34.

Dupont, C. 2013 'Le petit lot de coquilles de la structure de combustion' in J.-M. Large (ed) Les Batardières 2 (Saint-Vincent-sur-Jard, Vendée), Unpublished report, Rapport de fouille programmée en cours. 
Erlandson, J. M. and Moss M.L. 2001 'Shellfish feeders, carrion eaters, and the archaeology of aquatic adaptations', American Antiquity 66(3), 413-32. http://dx.doi.org/10.2307/2694242

Giazzon D. (ed) 2013 Une semi enceinte du Bronze final III, Mathieu, Calvados, Le Clos des Châtaigniers, Rapport de fouille de l'Institut national de recherches archéologiques préventives (INRAP), Caen: Service Régional de l'Archéologie de Basse-Normandie, inédit.

Gifford, E.W. 1939 'The Coast Yuki', Anthropos 34, 292-375.

Greengo, R.E. 1952 'Shellfish foods of the California Indians', Kroeber Anthropological Society Papers 7, 3-114.

Gutiérrez Zugasti, F.I. 2008 'Análisis tafonómico en arqueomalacología: el ejemplo de los concheros de la región cantábrica', Krei 10, 53-74.

Hayward, P.J. and Ryland, J.S. 1995 Handbook of the Marine Fauna of North-West Europe, Oxford: Oxford University Press.

Henshilwood, C., Nilssen, P. and Parkington, J. 1994 'Mussel drying and food atorage in the Late Holocene, SW Cape, South Africa', Journal of Field Archaeology 21(1), 103-9.

http://dx.doi.org/10.1179/jfa.1994.21.1.103

Kroeber, A.L. and Barrett S.A. 1960 Fishing among the Indians of Northwestern California, University of California Anthropological Records 21(1).

Law, M. 2012 'Shellfish and coastal exploitation' in Niall Sharples, 'The Beaker-period and Early Bronze Age settlement at Sligeanach, Cill Donnain' in M.P. Pearson (ed) From Machair to Moutains: Archaeological survey and excavation in South Uist, Oxford: Oxbow Books. 247-59

Lebon, M. 2010 'Caractérisation des ossements chauffés en contexte archéologique - Étude comparative de matériel moderne et fossile par spectroscopie infrarouge' in Théry-Parisot I., Chabal L., and Costamagno S. (eds) Taphonomie de la combustion des résidus organiques et des structures de combustion en contexte archéologique, Actes de la table 
ronde, 27-29 mai 2008, CEPAM, P@lethnologie 2. 149-162. http://www.palethnologie.org/2010-12-lebon/

Marlasca Martín, R. 2010 'El consumo de moluscos marinos por los primeros pobladores de las pitiusas (La Mola, Formentera, Islas Baleares)', Férvedes 6, 131-37.

McCarthy, A., Finlay, N. and McClean, O. 1999 'Marine molluscan remains' in P. Woodman, C. Peter, L. Anderson and N. Finlay (eds) Excavations at Ferriter's Cove, 1983-95: last foragers, first farmers in the Dingle Peninsula, Bray: Wordwell. 93-102.

McCormick, F., Gibbons, M., McCormac, F. and Moore, J. 1996 'Bronze Age to medieval coastal shell middens near Ballyconneely, Co. Galway', The Journal of Irish Archaeology 7, 77-84.

Meehan, B. 1977 'Hunters by the seashore', Journal of Human Evolution 6(4), 363-70. http://dx.doi.org/10.1016/S00472484(77)80005-5

Minniti, C. 2005 'Shells at the Bronze Age settlement of Coppa Nevigata (Apulia, Italy)', in D. Bar-Yosef Mayer (ed) Archaeomalacology: Molluscs in Former Environments of Human Behaviour, 9th ICAZ Conference, Durham 2002, Oxford: Oxbow Books. 71-81.

Mougne, C. in prep Exploitation des invertébrés marins (mollusques, crustacés et oursins) durant la Protohistoire sur le territoire littoral et continental de la façade atlantique et de la Manche de la France, PhD thesis, University of Rennes 1.

Mougne, C. and Dupont C. 2012 'Indices de consommation de coquillages marins au Bronze ancien sur le site Les Vallons de Luc à Luc-sur-Mer (Calvados)' in C. Marcigny (ed) Luc-sur-Mer (Calvados), 'Les vallons de Luc'. Habitats et parcellaire de l'âge du Bronze ancien, Unpublished report, Rapport de fouille de I'Institut national de recherches archéologiques préventives (INRAP), Caen: Service Régional de l'Archéologie de Basse-Normandie, inédit. 70-79.

Mougne, C., Dupont, C., Lepaumier, H. and Quesnel, L. 2013 'Exploitation of marine shells during the Late Iron Age: gathering territory, dietary 
choices and circulation networks. The example of Cormelles-le-Royal (Plain of Caen, Lower-Normandy, France)' in M.-Y. Daire C. Dupont, A. Baudry, C. Billard, J.M.Large, L. Lespez, E. Normand and C. Scarre (eds) Ancient Maritime Communities and the Relationship between People and Environment along the European Atlantic Coasts/Anciens peuplements littoraux et relations Homme/milieu sur les côtes de l'Europe Atlantique, Proceedings of the HOMER 2011 Conference, Vannes (France), Brit. Archaeol. Rep. Int. Ser. 2570, Oxford: Archaeopress. 527-34

Mougne, C. and Dupont, C. en collaboration avec Jahier, I., Le Goff, E., Lepaumier, H. and Quesnel, L. in press 'Les Gaulois et la pêche à pied en Plaine de Caen (Calvados): Pratiques alimentaires, économiques et cultuelles' in Les Gaulois au fil de l'eau, Actes du 37e colloque international de l'AFEAF, 8-11 mai 2013. Montpellier: Presses Universitaires des Lettres de Montpellier.

Muus, B.-J., Nielsen, J.-G., Dahlström, P. and Olesen Nyström, B. 2005 Guide des poissons de mer et de pêche, biologie, pêche, importance économique, Lausanne: Delachaux and Niestlé.

Oberg, K. 1973 The Social Economy of the Tlingit Indians, Seattle: University of Washington Press.

Poppe, T. and Goto, Y. 1991 European Seashells: Polyplacophora, Caudofoveata, Solenogastra, Gasteropoda, Germany: Verlag Christa Hemmen.

Poppe, T. and Goto, Y. 1993 European Seashells: Scaphopoda, Bivalvia, Cephalopoda, Germany: Verlag Christa Hemmen.

Prummel, W. 2002 'Molluscs from a Middle Bronze Age site and two Hellenistic sites in Thessaly, Greece' in D.E. Bar-Yosef Mayer (ed) Archaeomalacology: Molluscs in Former Environments of Human Behaviour, 9th ICAZ Conference, Durham 2002, Oxford: Oxbow Books. 107-21.

Quéro, J.-C., Vayne, J.-J. 1998 Les fruits de la mer et plantes marines des pêches françaises, Lausanne: Delachaux and Niestlé. 
Stewart, O.C. 1943 Notes on Pomo ethnogeography, Berkeley and Los Angeles: University of California Press.

Swanton, J.R. 1946 The Indians of the Southeastern United States, Bureau of American Ethnology Bulletin 137, Washington, D.C.: Government Printing Office.

Tebble, N. 1966 British Bivalve Seashells: a handbook for identification, London: British Musuem.

Teletchea, F. 2009 Guide des poissons de France, Côtes de l'Atlantique et de la Manche, Paris: Belin.

Terrell, J. 1967 'Galatea Bay: the excavation of a beach-stream midden site on Ponui Island in the Hauraki Gulf, New Zealand', Transactions of the Royal Society of New Zealand 2(3), 31-70.

Theodoropoulou, T. 2007 L'exploitation des ressources aquatiques en Egée septentrionale aux périodes pré- et protohistoriques, Unpublished PhD Thesis, University of Paris I Panthéon-Sorbonne.

Theodoropoulou, T. 2008 'Stratégies de pêche en Egée septentrionale au Néolithique et à l'âge du Bronze: paramètres environnementaux et culturels' in P. Béarez, S. Grouard and B. Clavel (eds) Archéologie du poisson, 30 ans d'archéo-ichtyologie au CNRS, Hommage aux travaux de Jean Desse et Nathalie Desse-Berset, 28e rencontres internationales d'archéologie et d'histoire d'Antibes et 14e ICAZ Fish remains working group meeting, APDCA, Antibes. 347-58.

Van Leeuwen C.H.A. 2012 Speeding up the snail's pace. Bird-mediated dispersal of aquatic organisms, Unpublished PhD Thesis, Radboud University Nijmegen, Nijmegen, The Netherlands: Ponsen and Looijen, Netherlands Institute of Ecology.

Van Neer, W. and Pieters, M. 1997 'Evidence for processing of flatfish at Raversijde, a Late Medieval coastal site in Belgium' in M. Kokabi and J. Wahl (eds) L'Homme et l'Animal, Anthropozoologica, 7 ème Congrès ICAZ, MNHN. 579-86. 
Waselkov, G.A. 1987 'Shellfish gathering and shell midden archaeology', Advances in Archaeological Method and Theory 10, 93-210.

Weydert, N. 1994 'Le dépôt coquillier anthropique de la Place Jules-Verne: Un témoignage de l'âge du Bronze à Marseille, Etude malacologique et archéologique', Préhistoire Anthropologie Méditerranéennes 3, 177-89.

Zazzo, A. 2010 'Géochimie isotopique des ossements brûlés: implications pour la reconstruction des régimes alimentaires et pour la datation par la méthode du radiocarbone' in Théry-Parisot I., Chabal L., and Costamagno S. (eds) Taphonomie de la combustion des résidus organiques et des structures de combustion en contexte archéologique, Actes de la table ronde, 27-29 mai 2008, CEPAM, P@lethnologie 2. 163-172.

http://www.palethnologie.org/2010-13-zazzo/ 